\title{
Bedrock channels in Pine Island Bay, West Antarctica
}

\author{
F. O. NITSCHE ${ }^{1 *}$, R. D. LARTER ${ }^{2}$, K. GOHL ${ }^{3}$, A. G. C. GRAHAM ${ }^{4} \&$ G. KUHN ${ }^{3}$ \\ ${ }^{1}$ Lamont-Doherty Earth Observatory, Columbia University, Palisades, New York 10964, USA \\ ${ }^{2}$ British Antarctic Survey, Natural Environment Research Council, High Cross, Madingley Road, Cambridge CB3 OET, UK \\ ${ }^{3}$ Alfred Wegener Institute, Helmholtz Centre for Polar and Marine Research, Am Alten Hafen 26, D-27568 Bremerhaven, Germany \\ ${ }^{4}$ College of Life and Environmental Sciences, University of Exeter, Rennes Drive, Exeter EX4 4RJ, UK \\ *Corresponding author (e-mail: fnitsche@ldeo.columbia.edu)
}

The seafloor of inner continental shelves on glaciated margins is sometimes stripped of most of the softer sediments, leaving bedrock exposed (Wellner et al. 2001). Examples of such exposed bedrock regions have been observed in the inner parts of several cross-shelf troughs on the West Antarctica margin, including those in the Amundsen Sea (Lowe \& Anderson 2003; Graham et al. 2009) and Marguerite Bay (Anderson \& Fretwell 2008). The detailed morphology of these areas consists of various features of glacial origin, predominantly parallel grooves or striations. These areas can also contain sinuous channels that are incised deeply into the rock substrate.

\section{Description}

Some prominent examples of channels eroded into exposed bedrock are found in Pine Island Bay in the Amundsen Sea, West Antarctica (Fig. 1a-c). The channels were first reported by Lowe \& Anderson (2003). They exhibit a range of sizes and orientations. The largest channels are as deep as 400-500 $\mathrm{m}$ and as wide as $1000-2000 \mathrm{~m}$ (Fig. 1e). Secondary channels are up to $10-$ $100 \mathrm{~m}$ deep and up to hundreds of metres wide. The minimum detectable size of channels is controlled by the spatial density of multibeam soundings on the seafloor, which were gridded at $35 \mathrm{~m}$ in this case; however, it is likely that smaller forms also exist.

A key characteristic that distinguishes channels from glacial grooves or lineations is their sinuous planforms (Fig. 1a-c). Whereas the large channels generally follow the palaeo-ice flow directions as indicated by sets of parallel grooves in the shallower banks between the channels, some of the smaller channels are oblique, sometimes almost perpendicular, to the palaeo-ice flow direction. In some cases along-axis channel depths increase from iceproximal to ice-distal settings, but in other cases they shoal downstream. Longer channels show significant variations in their depth, including undulations with positive and negative slopes (Fig. 1d).

\section{Interpretation}

The meandering character and frequent deviation of channels from the inferred palaeo-ice flow direction suggest that these features have not been simply cut by overriding ice. Instead, the sinuosity of the features is similar to channels produced by fluid flow and consequently they are widely interpreted as products of meltwater flow (Lowe \& Anderson 2003; Glasser \& Bennett 2004; Nitsche et al. 2013). Undulating channel thalwegs (Fig. 1d) further suggest that the features are formed by subglacial meltwater erosion, since overlying grounded ice is required to force meltwater to flow up- as well as down-slope (Smith et al. 2009).

Whereas the larger channels connect via flat-bottomed basins, the smaller channels are often orientated towards the larger channels and may act as feeder channels or tributaries to them. Together, the channel-and-basin landscape depicts an image of a widespread meltwater drainage network beneath the palaeo-ice sheet in Pine Island Bay.

Different scenarios are possible for the formation of the channels themselves. It is currently unclear whether these channels form through continuous 'steady-state' flow or via episodic drainage events. However, the deep incision of the larger channels suggests that they probably formed over multiple glacial cycles. Once channels are cut into the hard bedrock, subsequent subglacial meltwater flow is likely to re-occupy the same channels and continue to erode them further. Similar to channels connecting subglacial lakes under present-day ice sheets, some of these channels might at times be blocked by ice and only become active if water pressure exceeds a threshold allowing flow from one basin to another. So far, we do not have a clear indication of when or where different channels or channel systems were active. The fact that some channels contain sediment while others do not is a strong indication that the channels have not been active contemporaneously and, therefore, possess locally different histories of flow (Smith et al. 2009; Nitsche et al. 2013).

Detailed differences in bedrock geology that could influence the development and orientation of the channels are mostly unknown. In some cases the orientation and direction of the channels might be influenced by the location of 'weak' areas in the substrate (e.g. faults, bedrock structural lineaments and/or changes in geology), which also influence the flow of terrestrial river channels.

The dominant force driving subglacial meltwater flow is the hydrostatic potential generated by the thickness and surface slope of overlying ice. The influence of ice-surface changes on hydrostatic potential exceeds that of changes in bedrock topography by a factor of about 10 (Le Brocq et al. 2009). Subglacial water at or above hydrostatic pressure will therefore largely ignore the undulation (up and down variation) of the bottom of the channel axis, and flow according to variations in the ice surface (cf. Fig. 1c).

\section{References}

Anderson, J.B. \& Fretwell, L.O. 2008. Geomorphology of the onset area of a paleo-ice stream, Marguerite Bay, Antarctic Peninsula. Earth Surface Processes and Landforms, 33, 503-512.

Glasser, N.F. \& BenNetT, M.R. 2004. Glacial erosional landforms: origins and significance for palaeoglaciology. Progress in Physical Geography, 28, 43-75.

Graham, A.G.C., Larter, R.D., Gohl, K., Hillenbrand, C.-D., Smith, J.A. \& Kunn, G. 2009. Bedform signature of a West Antarctic palaeo-ice stream reveals a multi-temporal record of flow and substrate control. Quaternary Science Reviews, 28, 2774-2793.

Le Brocq, A.M., Payne, A.J., Siegert, M.J. \& Alley, R.B. 2009. A subglacial water-flow model for West Antarctica. Journal of Glaciology, $\mathbf{5 5}, 879-888$.

Lowe, A.L. \& ANDERson, J.B. 2003. Evidence for abundant subglacial meltwater beneath the paleo-ice sheet in Pine Island Bay, Antarctica. Journal of Glaciology, 49, 125-138.

Nitsche, F.O., GoHL, K. ET AL. 2013. Paleo ice flow and subglacial meltwater dynamics in Pine Island Bay, West Antarctica. The Cryosphere, 7, 249-262.

Smith, J.A., Hillenbrand, C.-D., Larter, R.D., Graham, A.G.C. \& Kunn, G. 2009. The sediment infill of subglacial meltwater channels on the West Antarctic continental shelf. Quaternary Research, 71, 190-200.

Wellner, J.S., Lowe, A.L., ShipP, S.S. \& ANDERSon, J.B. 2001. Distribution of glacial geomorphic features on the Antarctic continental shelf and correlation with substrate: implications for ice behavior. Journal of Glaciology, 47, 397-411.

From: Dowdeswell, J. A., Canals, M., Jakobsson, M., Todd, B. J., Dowdeswell, E. K. \& Hogan, K. A. (eds) 2016. Atlas of Submarine Glacial Landforms: Modern, Quaternary and Ancient. Geological Society, London, Memoirs, 46, 217-218, http://doi.org/10.1144/M46.1 (C) 2016 The Author(s). Published by The Geological Society of London. All rights reserved. For permissions: http://www.geolsoc.org.uk/permissions. Publishing disclaimer: www.geolsoc.org.uk/pub_ethics 

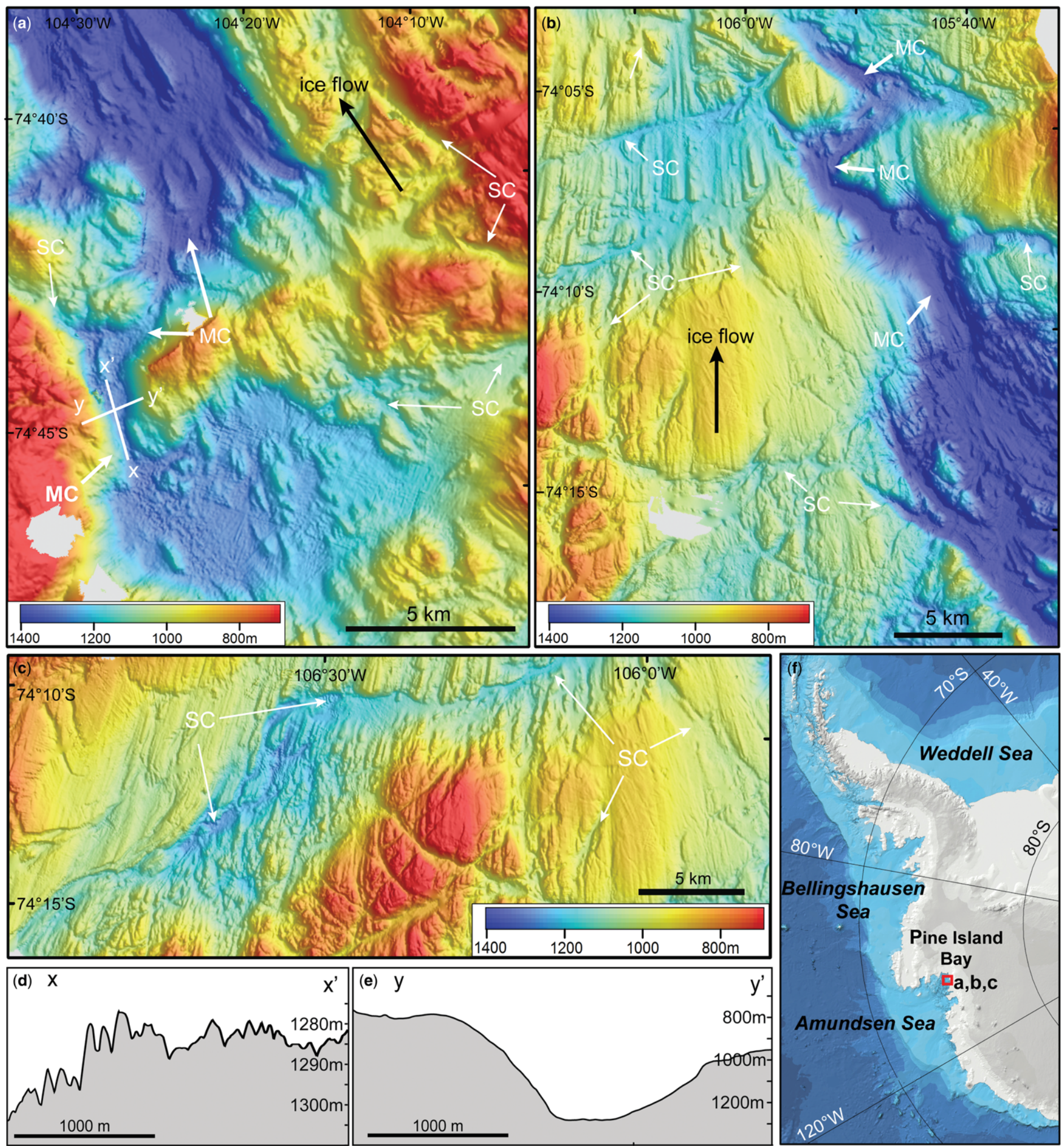

Fig. 1. Multibeam bathymetry and cross-profiles of bedrock channels in Pine Island Bay, West Antarctica. (a-c) Sun-illuminated multibeam-bathymetric images showing examples of bedrock channels of various sizes from the same channel basin (Nitsche et al. 2013). White arrows point to major channels (MC, thick arrow) and secondary channels (SC, thin arrow). Black arrows indicate palaeo-ice flow direction. Acquisition systems Kongsberg EM120 and Hydrosweep DS2. Frequency $12 \mathrm{kHz}$. Grid-cell size $35 \mathrm{~m}$. White lines in (a) indicate location of (d) and (e). (d) Along-channel profile of a larger channel showing variations and shoaling of channel depths downstream. (e) Seafloor profile of a large channel showing steep sides and channel dimensions. (f) Location of study area (red box; map from IBCSO v. 1.0). 